\title{
A comprehensive overview of role of combined myoinositol and D-chiroinositol (40:1 ratio) therapy in the management of PCOS
}

\author{
Abhijeet G Malvi, Alok Chaturvedi, Sonal V Mehta, Kishore R Sonkusare, Nilanj S Dave
}

Correspondence: Dr Abhijeet G Malvi, Senior Manager, Medical Affairs, Intas

Pharmaceuticals Ltd, Ahmedabad, Gujrat, India; Email -

abhijeet_malvi@intaspharma.com

Distributed under Attribution-NonCommercial-ShareAlike 4.0 International (CC BY-NC-SA 4.0)

\begin{abstract}
Polycystic Ovarian Syndrome (PCOS) is one of the most common metabolic and reproductive ailment among reproductive age group women. PCOS patients present with a constellation of signs and symptoms associated with menstrual dysfunction and androgen excess, which significantly impacts quality of life. Women with PCOS is at increased risk of various morbidities, which includes obesity, insulin resistance, type II diabetes mellitus, cardiovascular disease (CVD), infertility, cancer, and psychological disorders. Exact pathophysiology of PCOS is poorly understood although studies have suggested an important role of insulin resistance and/or resultant compensatory hyperinsulinemia. Deficiency in the usage and/or tissue availability of myoinositol (MI) and/or Dchiroinositol (DCI) in PCOS patients could likely lead to insulin resistance typical of this syndrome. Recent studies have demonstrated that combined supplement containing both MI + DCI in their physiological plasma ratio 40:1 is able to improve the endocrine profile, ovarian function and the insulin resistance in PCOS patients. The aim of the present review was to summarize currently available data on the MI+DCI $(40: 1)$ combination therapy in PCOS patients.
\end{abstract}

Keywords: Polycystic ovary syndrome, myoinositol, D-chiroinositol, insulin resistance.

In modern medical era, polycystic ovary syndrome (PCOS) was first described by Stein and Leventhal in 1935, who studied seven females with amenorrhea, hirsutism and enlarged ovaries with multiple cysts. ${ }^{1}$ PCOS is now recognized as a common, heterogeneous, heritable disease affecting females throughout their lifetime. It is most common cause of hyperandrogenism and oligo/anovulation leading to notable psychological, social, and financial consequences. ${ }^{2}$ The prevalence of PCOS has shown significant rise from $8 \%$ to almost $20 \%$ globally within the past two decades. ${ }^{3}$ Studies conducted on PCOS in India showed a prevalence ranging from $3.7 \%$ to 22.5 $\%{ }^{4,5}$ (with $9 \%$ to $36 \%$ prevalence in adolescents). ${ }^{6,7}$ In Indian subcontinent, PCOS prevalence rate amongst infertile women is high (upto 50-60\%). ${ }^{8}$

Clinical symptoms and conditions associated with polycystic ovary syndrome ${ }^{9,10}$ (Figure 1)

As per Rotterdam criteria which is widely followed

Received: $28^{\text {th }}$ September 2018. Accepted: $26^{\text {th }}$ December 2018.

Malvi AG, Chaturvedi A, Mehta SV, Sonkusare KR, Dave NS. A comprehensive overview of role of combined myoinositol and D-chiroinositol (40:1 ratio) therapy in the management of PCOS. The New Indian Journal of OBGYN. 2019; 5(2):71-8 
Figure 1: Clinical signs and symptoms of $\operatorname{PCOS}^{9,10}$

\begin{tabular}{|c|c|}
\hline $\begin{array}{l}\text { Manifestations of } \\
\text { Hyperandrogenism }\end{array}$ & $\begin{array}{l}\text {-Acne } \\
\text { - Hirsutism } \\
\text { - Alopecia } \\
\text { - Acanthosis nigricans }\end{array}$ \\
\hline Menstrual irregularity & $\begin{array}{l}\text { - Oligomenorrhea } \\
\text {-Amenorrhoea }\end{array}$ \\
\hline Ultrasonographic findings & $\begin{array}{l}\cdot \geq 12 \text { follicles in each ovary } \\
\text { Follicle size between } 2 \text { to } 9 \mathrm{~mm} \text { with or without } 10 \mathrm{ml} \text { ovarian } \\
\text { voulme }\end{array}$ \\
\hline Associated morbidities & $\begin{array}{l}\text { - Obesity } \\
\text { - Insulin resistance } \\
\text { - Type } 2 \text { diabetes mellitus } \\
\text { - cardiovascular disease } \\
\text { - Dyslipidemia } \\
\text { - Metabolic syndrome } \\
\text { - Mood disorders } \\
\text { - infertility } \\
\text { - psychological disorders: depression,anxiety }\end{array}$ \\
\hline
\end{tabular}

across Asia, Europe and Australia, "1 for stating the presence of PCOS, at least two of the following three criteria should to be present: (i) Oligo-or anovulation (ii) Biochemical or clinical indication of hyperandrogenism; and (iii) presence of polycystic ovaries at ultrasound or presence of 12 or more follicles with a diameter of 2 to 9 $\mathrm{mm}$ in each ovary, and/or raised ovarian volume $(>10$ $\mathrm{ml}){ }^{12}$

\section{Role of Insulin Resistance in PCOS pathophysiology}

Exact pathophysiology of PCOS is still poorly understood. PCOS is a multifactorial disorder that results from complex interactions between genetic and environmental factors. ${ }^{13}$ Familial clustering, linkage and association studies have shown candidate genes for PCOS with autosomal dominant trait and low penetrance. ${ }^{3}$ Current knowledge of PCOS pathophysiology indicates substantial role played by insulin resistance. Insulin resistance is observed in upto 50-90\% of PCOS patients. ${ }^{14}$ Compensatory hyperinsulinemia acts synergistically with luteinizing hormone (LH) as a co-gonadotrophin within ovarian theca cells. ${ }^{15}$ Resultant activation of CYP17 encodes P450c17 $\alpha$ which is a very important enzyme for androgen biosynthesis. ${ }^{16}$ Acting within the ovary, insulin promotes arrest of pre-antral follicle growth and development. $^{17}$
Extra-ovarian pleiotropic effects of hyperinsulinemia involves augmentation of $\mathrm{LH}$ pulse amplitude, ${ }^{18}$ enhancing adrenal $\mathrm{P} 450 \mathrm{c} 17 \alpha$ activity and restraint of hepatic sex hormone binding globulin (SHBG) production. ${ }^{19}$ Weight gain and obesity can worsen insulin resistance in PCOS. $^{20}$ Decreased insulin sensitivity is observed both in obese as well as lean PCOS patients. ${ }^{21}$ Insulin resistance can lead to diabetes, metabolic syndrome, thus predisposing PCOS patients to cardiovascular risk. ${ }^{20}$ An overview of peripheral insulin resistance and its role in the pathogenesis of PCOS is depicted in Figure 2. ${ }^{20,22}$

\section{Role of inositol in Insulin-signaling pathways}

Insulin-signaling pathways involve mediators like inositol phosphoglycans (IPGs). Phosphatidyl-myoinositol acts as precursors of phosphatidyl inositolbisphosphate/ triphosphate and is important for production and activation of PI3 kinase, thus playing an important role in insulin signal transduction pathway. ${ }^{23} \mathrm{D}$-chiroinositol also has a potential role as a putative mediator of insulin action. D-chiroinositol is involved in stimulation of pyruvate dehydrogenase phosphatase, protein phosphatase 2C facilitating glucose disposal. ${ }^{24}$ Inositol deficiency can impair insulin action leading to insulin resistance. ${ }^{25}$ The overview of importance of 
The New Indian Journal of OBGYN. 2019 (January-June); 5(2)

inositol in insulin signal transduction pathway is shown

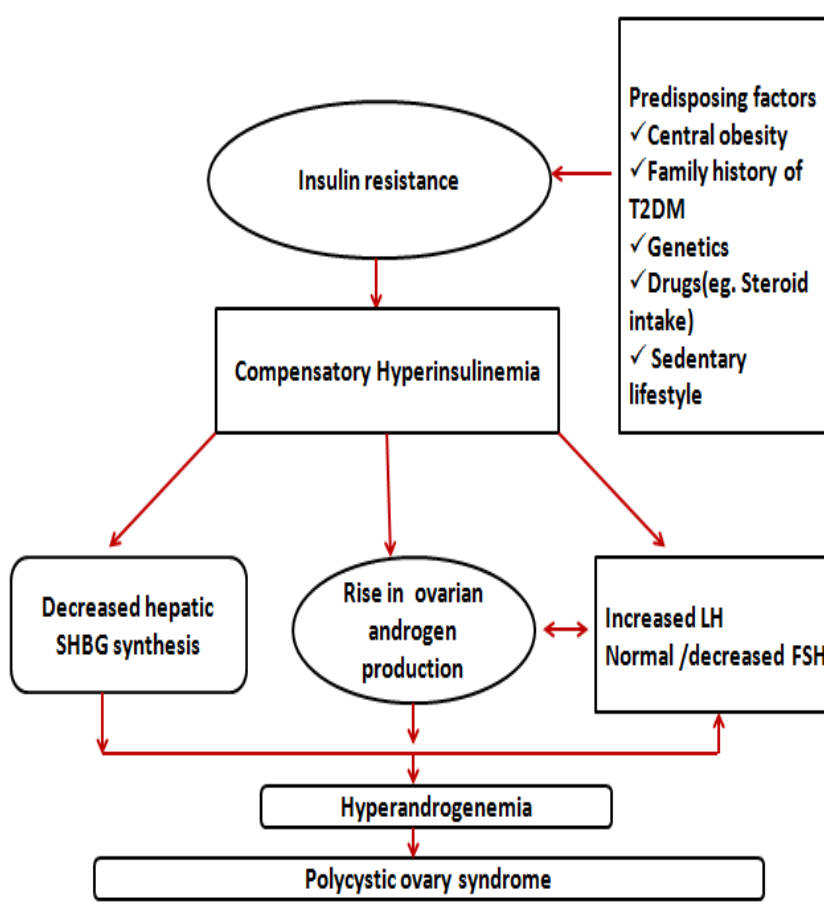

Figure 2: Role of Insulin resistance in PCOS. ${ }^{20,22}$ below Figure $3 .{ }^{26}$ Available data suggest inositol deficiency in insulin-resistant women having PCOS. ${ }^{24}$ These women have lower serum D-chiroinositol levels and elevated urinary loss of D-chiroinositol-IPG. ${ }^{27}$ The dysregulated metabolism of inositol in PCOS highlights

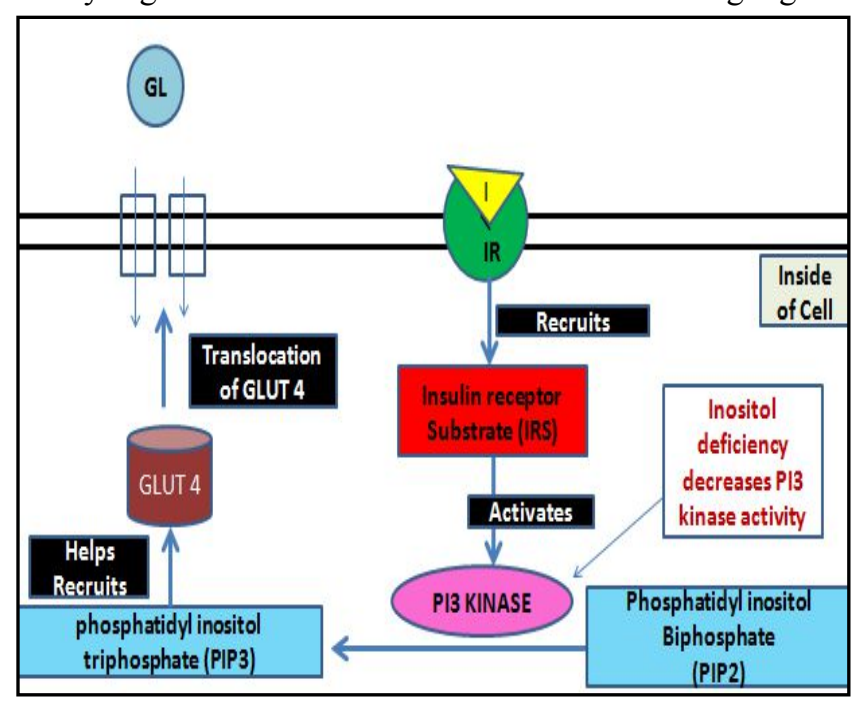

Figure 3: Insulin signal transduction pathway. ${ }^{26}$ subtle connection between inositol deficiency and insulin resistance in PCOS patients. ${ }^{28}$

\section{Insulin sensitizers for management of PCOS}

Recently insulin-sensitizing agents have been proposed as a therapy for the treatment of PCOS. These agents act by increasing insulin sensitivity leading to decrease in hyperinsulinemia. ${ }^{29}$ Since decreased insulin sensitivity is observed both in obese and lean PCOS patients ${ }^{21}$ use of insulin sensitizers are being advocated in most patients with PCOS. Insulin sensitizer treatment has been shown to be resulting in reduction of serum androgen levels and gonadotropins, improvement of serum lipids, metabolic comorbidities. ${ }^{29}$ This therapy has also been shown to regularize the menstrual cycle, improve ovulation and fertility and decrease hirsutism and acne. ${ }^{29}$ Commonly used insulin sensitizers for PCOS include metformin, myoinositol, and thiazolidinedione. Metformin although effective in counteracting hyperandrogenism in the short term in obese, insulin-resistant PCOS women ${ }^{30}$ but published study reports that non obese women PCOS women had no benefit from metformin. ${ }^{31}$ Metformin is shown to have a detrimental effect on follicle number and quality. ${ }^{32}$ Baillargeon et al (2004) have shown that benefits imparted by metformin in PCOS can be attributed to its ability to improve insulin-mediated release of DCI-IPG mediators. ${ }^{33}$ Nausea, diarrhoea, and weight gain observed with metformin reduce patient's compliance to therapy. ${ }^{34}$ Nevertheless the use of thiazolidinediones is associated with weight gain, cardiovascular events, fragility fractures and bladder cancer. $^{35}$

\section{Inositols}

Inositol is polysugar alcohol that belongs to vitamin BComplex group. ${ }^{25}$ Inositol exists as nine isomers. ${ }^{25}$ The myoinositol and D-chiroinositol are the two main stereoisomers present in human body. ${ }^{36}$ Inositol is found concentrated in the phospholipids in many foods, such as cereals, nuts, fruits and animal tissues. ${ }^{37}$ Each tissue has its own MI/DCI ratio and the relative proportion of each inositol in a particular tissue is reflective of inositol specific functions. ${ }^{38}$ This ratio within the cell is maintained via direct enzymatic transformation of MI to DCI through insulin dependent enzyme epimerase as per 
the tissue requirement.(39)In plasma, the physiological ratio of MI: DCI is shown to be 40:1 ${ }^{39}$

Myoinositol: MI, an essential component in eukaryotic cell membranes is the most abundant inositol found in nature. ${ }^{40}$ Myoinositol plays an important role in several biological processes like insulin mediated signals transmission, cytoskeleton assembly, gametogenesis, intracellular calcium concentration regulation, maintenance of membrane potential, regulation of gene expression. ${ }^{41}$ Myoinositol controls the activities of several hormones such as follicle stimulating hormone (FSH), insulin, thyroid stimulating hormone (TSH). ${ }^{39} \mathrm{MI}$ is involved in cellular glucose uptake, it raises ovarian energy status and hence it is able to improve oocyte quality. ${ }^{38}$

D-chiroinositol (DCI). It is a product of the epimerization of the MI. DCI is important for glycogen synthesis. High concentrations of DCI is present in glycogen storage tissues, such as liver, muscles, fat and low concentration is present in those tissues with high glucose utilization such as brain, ovary, heart. ${ }^{38}$

Both the isoforms of inositol individually were found to be effective in improving ovarian function and metabolism in patients with PCOS. ${ }^{42}$ Myoinositol showed the most marked effect on the metabolic profile, whereas D-chiroinositol caused better reduction of hyperandrogenism. ${ }^{42}$

\section{Rationale of MI +DCI (40:1) ratio supplementation in PCOS}

Epimerase is an insulin dependent enzyme. ${ }^{43}$ In PCOS, the insulin resistant tissues have low DCI level due to reduced epimerase activity, on the other hand insulin sensitive tissues like ovary have increased epimerase activity causing enhanced conversion of MI to DCI depleting MI level. ${ }^{43}$ In follicular fluid normal MI/DCI ratio is nearly 100:1 while in PCOS women that ratio is only $0.2: 1^{35}$ (DCI paradox). In PCOS, peripherally reduced DCI augments insulin-resistance and worsens the metabolic features ${ }^{44}$ while reduced MI blocks synthesis of phosphatidyl-MI that lead to lack of transmission of FSH signals which might be responsible for chronic anovulation in PCOS patients. ${ }^{39}$ Reduced levels of MI decreases oocyte quality by interfering with physiological follicular maturation. ${ }^{44}$ Hence to restore disturbed inositol balance in various tissues particularly in ovary, there is need of MI and DCI supplementation in their physiological ratio of 40:1. As MI and DCI regulate different biological processes, concomitant administration has synergistic action which is more beneficial than MI alone and DCI alone in PCOS. ${ }^{45,46}$ DCI is speculated to rapidly cause reduction in the peripheral hyperinsulinemia while MI mainly cause improvement in the ovulatory function. ${ }^{45}$ Supplementation of $\mathrm{MI}$ and DCI, in a physiological ratio (40:1), ensure better clinical results both at ovarian and non-ovarian level. ${ }^{45}$

Potential benefits of supplementation of MI/DCI in ratio 40:1

$\checkmark$ There is better reduction of insulin resistance, androgens levels, and cardiovascular risk. ${ }^{39}$

$\checkmark$ There is better restoration of spontaneous ovulation and menstrual cycle. ${ }^{39}$

$\checkmark$ Improvement with combination is more quicker compared to MI alone. ${ }^{46}$

$\checkmark$ Better results in terms of weight reduction, resumption of spontaneous ovulation, and spontaneous pregnancy compared with metformin. $^{47}$

The 2013 Florence International Consensus Conference on myoinositol and D-chiro-inositol in obstetrics and gynaecology have answered many research questions pertaining to the use of these two stereoisomers. Overall evidence from the literature analyzed by the Conference scientific Committee points out that for PCOS, treatment based on the association of MI and DCI in the physiological ratio(40:1) can be the most appropriate and, could be a predictive factor in improving assisted reproductive technology (ART) outcome. . $^{48,49}$

\section{Clinical outcomes of the MI +DCI combination in ratio 40:1 in PCOS patients.}

The available studies of MI+DCI combination are summarized in below. ${ }^{45-47,50-52}$ (Table 1).

\section{Safety}

Being a naturally occurring substance in the human body as well as in plants, both myoinositol and Dchiroinositol are considered as safe drugs. Inositols are better tolerated. ${ }^{53}$ The safety data of the myoinositol trials report mild side effects such as, nausea and one of flatus and mild insomnia only at $12 \mathrm{~g}$ /day or higher. ${ }^{54}$ Isabella et al. (2012) showed that a safety threshold for DCI 
The New Indian Journal of OBGYN. 2019 (January-June); 5(2)

supplementation in PCOS patients may be set at 300 patients ${ }^{54}$ showed that no relevant side effects of MI+DCI

Table 1: The available studies of MI+DCI combination ${ }^{45-47,50-52}$

\begin{tabular}{|c|c|c|c|c|}
\hline Author & $\begin{array}{l}\text { Study design \& } \\
\text { Study size }\end{array}$ & $\begin{array}{l}\text { Population } \\
\text { Characteris tic }\end{array}$ & $\begin{array}{l}\text { Type of } \\
\text { treatment }\end{array}$ & Main findings \\
\hline $\begin{array}{c}\text { Nordio et al } \\
2012^{45}\end{array}$ & $\begin{array}{l}\text { Randomized } \\
\text { controlled trial in } \\
50 \text { women with } \\
\text { PCOS.MI+DCI } \\
\text { group: } 26 \\
\text { MI only group: } 24\end{array}$ & $\begin{array}{l}\text { Women with } \\
\text { PCOS (BMI }> \\
27 \mathrm{~kg} / \mathrm{m} 2 \\
\text { Mean age } 28 \\
\text { years } \\
\text { range }(18-41)\end{array}$ & $\begin{array}{l}\text { MI+DCI group: } \\
550 \mathrm{mg} \text { of } \mathrm{MI}+ \\
13,8 \mathrm{mg} \text { of DCI } \\
\text { twice daily for } 6 \\
\text { months. } \\
\text { MI only group: } 2 \mathrm{~g} \\
\text { of MI for } 6 \text { months. }\end{array}$ & $\begin{array}{l}\text { At } 3 \text { months, compared to MI group in MI +DCI group ,there was } \\
\text { significant reduction in Fasting glucose }(\mathrm{p}<0.05) \text {, Glucose } \\
\text { AUC }(\mathrm{p}<0.05) \text {,Fasting insulin }(\mathrm{p}<0.03) \text { and Insulin AUC }(\mathrm{p} \\
<0.05) \text {.Compared to the MI group, the decrement of total testosterone and } \\
\text { the increment of the serum sex hormone binding globulin were more } \\
\text { relevant in MI+DCI group both at } 3 \text { month and at } 6 \text { month. In both groups } \\
\text { there was a striking improvement of the ovulation function. }\end{array}$ \\
\hline $\begin{array}{c}\text { Abdelhamid } \\
\text { et .al } \\
2015^{47}\end{array}$ & $\begin{array}{l}\text { Case-control } \\
\text { study in } 128 \\
\text { PCOS Patients } \\
\text { MI+DCI group: } 62 \\
\text { patients } \\
\text { Metformin } \\
\text { group:66 Patients }\end{array}$ & $\begin{array}{c}\text { Diagnosed } \\
\text { PCOS females } \\
\text { with } \\
\text { clomiphene } \\
\text { resistance } \\
\text { Age: } 20-35 \text { yrs } \\
\text { BMI less than } \\
30 \mathrm{~kg} / \mathrm{m} 2, \\
\text { Failed caloric } \\
\text { diet. }\end{array}$ & $\begin{array}{l}\text { MI+DCI group: } \\
1 \mathrm{~g} \mathrm{MI}+25 \mathrm{mg} \\
\text { DCI }+200 \mathrm{mg} \\
\text { Folic acid; } 2 \text { tablets } \\
\text { per day for } 3 \\
\text { months } \\
\text { Metformin group: } \\
\text { Metformin } 500 \mathrm{mg} \\
\text { tablets } 3 \text { times per } \\
\text { day for } 3 \text { months }\end{array}$ & $\begin{array}{l}\text { Compared to metfomingroup, in MI+DCI group significantly higher number } \\
\text { of patients achieved spontaneous menstruation }(\mathrm{p}<0.05) \text { and spontaneous } \\
\text { pregnancy. }(\mathrm{p}<0.05) \text {. } \\
\text { Number of patients with }>10 \% \text { weight loss were significantly higher in } \\
\text { MI+DCI group than metformin group. }(\mathrm{p}<0.05) \text {. } \\
\text { There was significant difference in progesterone level, which was }>12 \mathrm{ng} / \mathrm{ml} \\
(\mathrm{p}<0.05) \text {. There was no statistically significant difference in terms of AMH } \\
\text { decrease and HOMA-IR. Results of the paired t-test performed to compare } \\
\text { each outcome in both groups showed significant results in the other outcome } \\
\text { parameters, such as weight loss, spontaneous ovulation and spontaneous } \\
\text { pregnancy, in favor of the MI+DCI group. } \mathrm{p}<0.05\end{array}$ \\
\hline $\begin{array}{l}\text { Benelli et } \\
\text { al } 2016^{50}\end{array}$ & $\begin{array}{l}\text { Randomized } \\
\text { controlled } \\
\text { Trial in } 46 \text { obese } \\
\text { PCOS Women } \\
\text { MI+DCI group: } 21 \\
\text { patients } \\
\text { Folic acid group: } \\
25 \text { patients }\end{array}$ & $\begin{array}{c}\text { PCOS } \\
\text { Women } \\
\text { With } \mathrm{BMI}>30 \\
\mathrm{~kg}\end{array}$ & $\begin{array}{l}\text { MI+DCI group: } \\
\text { MI }(550 \mathrm{mg})+\mathrm{DCI} \\
(13.8 \mathrm{mg})+\text { folic } \\
\text { acid }(200 \mathrm{mcg}) \\
\text { capsule twice a day } \\
\text { for } 6 \text { months } \\
\text { Folate group: } \\
200 \mathrm{mcg} \text { of folic } \\
\text { acid, twice a day } \\
\text { for6 months }\end{array}$ & $\begin{array}{l}\text { Only in the group treated with the MI }+ \text { DCI , there was statistically } \\
\text { significant reduction from baseline in } \\
\checkmark \quad \text { LH }(\mathrm{p}<0.05) \text {, } \\
\checkmark \quad \text { free testosterone }(\mathrm{ng} / \mathrm{dl})(\mathrm{p}<0.05), \\
\checkmark \quad \text { fasting insulin }(\mathrm{p}<0.001) \\
\checkmark \quad \text { HOMA index }(\mathrm{p}<0.05) \text {. } \\
\text { Statistically significant increase of } 17 \text {-beta-Estradiol levels in MI+DCI } \\
\text { group. }\end{array}$ \\
\hline $\begin{array}{l}\text { Minozzi et } \\
\text { al. } 2013^{51}\end{array}$ & $\begin{array}{c}\text { Longitudinal } \\
\text { observation study } \\
\text { in } 20 \text { women with } \\
\text { PCOS. }\end{array}$ & $\begin{array}{l}\text { Obese, } \\
\text { caucasian } \\
\text { PCOS } \\
\text { women. }\end{array}$ & $\begin{array}{c}\text { Patients received } \\
550 \mathrm{mg} \mathrm{MI}+ \\
13.8 \mathrm{mg} \text { DCI twice } \\
\text { a day for } 6 \text { months. }\end{array}$ & $\begin{array}{l}\text { After } 6 \text { months of combined therapy, LDL levels were significantly reduced } \\
\text { compared with baseline levels }(p<0.05) \text {. There was significant increase in } \\
\text { HDL }(p<0.05) \text { and significant decrease in triglycerides }(p<0.05) \text {. } \\
\text { There was significant reduction of the HOMA index }(p<0.05) \text { and glucose } \\
(p<0.05) \text { and insulin levels. }(p<0.05) \text {. }\end{array}$ \\
\hline $\begin{array}{l}\text { Pande } M \text { et } \\
\text { al. } 2017^{52}\end{array}$ & $\begin{array}{l}\text { Randomized } \\
\text { controlled } \\
\text { Trial in } 140 \\
\text { obese PCOS } \\
\text { Women } \\
\text { MI+DCI group:70 } \\
\text { patients } \\
\text { Myoinositol } \\
\text { group: } 70 \text { patients }\end{array}$ & $\begin{array}{l}\text { Overweight } \\
\text { (BMI>27) } \\
\text { women } \\
\text { satisfying } \\
\text { Rotterdam } \\
\text { criteria for } \\
\text { diagnosis of } \\
\text { PCOS. }\end{array}$ & $\begin{array}{c}\text { MI+DCI group: } \\
\text { MI (550 mg)+DCI } \\
\text { (13.8mg) one tablet } \\
\text { twice a day for } 6 \\
\text { months } \\
\text { Myoinositol group: } \\
\text { Myoinositol } 1 \mathrm{gm} \\
\text { twice a day for } 6 \\
\text { months }\end{array}$ & $\begin{array}{l}\checkmark \text { Combination provided significant decrease in BMI, W:H ratio, } \\
\text { Diastolic BP, Fasting blood sugar at end of both 3rd and 6th month, } \\
\text { ]for LDL it was at the end of } 3 \text { months. } \\
\checkmark \quad \text { This combination also increased the HDL level significantly in both } \\
\text { the occasions }\end{array}$ \\
\hline
\end{tabular}

$\mathrm{mg} \mathrm{DCI} /$ day, the highest dose that will not reduce oocyte maturation. ${ }^{38}$ Benelli et al.(2016) study in PCOS patients ${ }^{50}$ and Pintaudi et al (2016) study in type 2 diabetes combination in ration 40:1 during therapy providing further evidence of the safety of the usage of these inositols in combination. 


\section{Conclusion}

Myoinositol, a second messenger regulating many hormones such Follicle Stimulating Hormone (FSH) and insulin, positively affects different pathways at both ovarian and non-ovarian level, while D-chiroinositol by inhibiting the negative consequences of hyperinsulinemia exerts beneficial effects mainly in non-ovarian tissues. Synergistic action of concomitant administration of MI and DCI in their physiological plasma ratio (40:1) seems to be more beneficial than MI alone or DCI alone in PCOS women. Available clinical data demonstrates combined inositol supplementation in their physiological ration could fruitfully affect different pathophysiological aspects of PCOS and improves endocrine, metabolic ,ovarian and ,reproductive disturbances of PCOS .Owing to better therapeutic efficacy, safety and tolerability profile, MI+DCI (40:1) combination can be an attractive option in management of PCOS .

\section{Conflict of interest: None. Disclaimer: Nil.}

\section{References}

1.Stein IF, Leventhal ML. Amenorrhea associated with bilateral polycystic ovaries. Am J Obstet Gynecol 1935;29:181-91.

2.Norman R, Dewailly D, Legro R, Hickey T. Polycystic ovary syndrome. Lancet. 2007; 370: 685-97.

3.Meera Krishna B, Laloraya M. Insulin paradox and polycystic ovarian syndrome:implications on mechanism and pathogenesis. Health Sciences. 2013;2(1):1-12.

4.Gill H, Tiwari P, Dabadghao P. Prevalence of polycystic ovary syndrome in young women from North India:A Community-based study. Indian. J. Endocrinol. Metab 2012;16(Suppl 2):S389-92.

5.Joshi B, Mukherjee S, Patil A, Purandare A, Chauhan S, Vaidya R. A cross-sectional study of polycystic ovarian syndrome among adolescent and young girls in Mumbai, India. Indian. J. Endocrinol Metab. 2014;18(3):317-24.

6.Nair MK, Pappachan P, Balakrishnan S, Leena ML, George B, Russell PS. Menstrual irregularity and polycystic ovarian syndrome among adolescent girls - a 2 year followup study. Indian .J Pediatr. 2012; 79(Suppl 1):S69-S73.

7.Allahbadia GN, Merchant R. Polycystic ovary syndrome in the Indian subcontinent. Semin Reprod Med. 2008; 26(1):2234.
8.Jajoo S. Angik R. Epidemiological study of clinical characteristics of patients with PCOS attending infertility clinic and awareness of PCOS in a rural set up. Int J Reprod Contracept Obstet Gynecol. 2013 Dec; 2(4): 528-32.

9.Rojas J, Chávez M, Olivar L, Rojas M, Morillo J, Mejías J, et al. Polycystic Ovary Syndrome, Insulin Resistance, and Obesity: Navigating the Pathophysiologic Labyrinth. International Journal of Reproductive Medicine. 2014:1-17.

10.El Hayek S, Bitar L, Hamdar H. Polycystic Ovarian Syndrome: An Updated Overview. Front. Physiol. 2016; 7:124

11.Boyle J, Teede H. Polycystic ovary syndrome An update. Australian Family Physician. 2012; 41(10): 752-56.

12.Rotterdam ESHRE/ASRM-Sponsored PCOS Consensus Workshop Group. Revised 2003 consensus on diagnostic criteria and long-term health risks related to polycystic ovary syndrome. Fertil Steril. 2004; 81(1):19-25.

13. Melo A, Dias S, Carvalho P, Cardoso V, Bettiol H, Barbieri M, et al. Pathogenesis of polycystic ovary syndrome:multifactorial assessment from the foetal stage to menopause. Reproduction. 2015;150(1):R11-R24.

14.Venkatesan AM, Dunaif A, Corbould A. Insulin resistance in poly-cystic ovary syndrome: progress and paradoxes. Recent Prog Horm Res. 2001; 56: 295-308.

15.Franks S, Mason H, White D, Willis D. Mechanisms of anovulation in polycystic ovary syndrome. Steroids. 1997;62:728

16.Morin-Papunen LC, Vauhkonen I, Koivunen RM, Ruokonen A, Tapanainen JS. Insulin sensitivity, insulin secretion, and metabolic and hormonal parameters in healthy women and women with polycystic ovarian syndrome. Hum Reprod. 2000;15(6):1266-74.

17.Willis DS, Watson H, Mason HD, Galea R, Brincat M, Franks S. Premature response to luteinizing hormone of granulosa cells from anovulatory women with polycystic ovary syndrome: relevance to mechanism of anovulation. $\mathrm{J}$ Clin Endocrinol Metab. 1998; 83(11):3984-91.

18.Dunaif A. Insulin resistance and the polycystic ovary syndrome: mechanism and implications for pathogenesis. Endocr Rev. 1997;18(6):774-800.

19. Yki-Jarvinen H, Makimattila S, Utriainen T, Rutanen EM. Portal insulin concentrations rather than insulin sensitivity regulate serum sex hormone-binding globulin and insulin-like growth factor binding protein 1 in vivo. J Clin Endocrinol Metab. 1995; 80(11):3227-32.

20.Barber T, Dimitriadis G, Andreou A, Franks S. Polycystic Ovary Syndrome: Insights into pathogenesis and a common 
association with insulin resistance. Clinical Medicine. 2016;16(3):262-66.

21.Kowalska I, Straczkowski M, Nikolajuk A, Adamska A, Karczewska-Kupczewska M, Otziomek E, et al. Serum visfatin in relation to insulin resistance and markers of hyperandrogenism in lean and obese women with polycystic ovary syndrome. Human Reproduction. 2007; 22(7):1824-9.

22.Nestler J. Metformin for the treatment of the Polycystic Ovary Syndrome. NEJM. 2008; 358(1):47-54.

23.Di Paolo G, De Camilli P. Phosphoinositides in cell regulation and membrane dynamics. Nature. 2006; 443(7112):651-7

24.Larner J. D-Chiro-Inositol - Its Functional role in insulin action and its deficit in insulin resistance. Int. Jnl. Experimental Diab. Res. 2002; 3(1):47-60.

25.Govindarajan C, Pitchaipillai R, Shanmugasundaram B, Thangam S, Arokiasamy J, Subramania Pillai M. Myoinositol: a review of its use in patients with polycystic ovary syndrome. World Journal of Pharmacy and Pharmaceutical Sciences. 2015; 4(6):137-55.

26.Jewell J, Oh E, Thurmond D. Exocytosis mechanisms underlying insulin release and glucose uptake: conserved roles for Munc18c and syntaxin. Am J Physiol Regul Integr Comp Physiol. 2010.298(3):517-31.

27.Baillargeon J, Nestler J, Ostlund R, Apridonidze T, Diamanti-Kandarakis E. Greek Hyperinsulinemic women, with or without polycystic ovary syndrome, display altered inositols metabolism. Human Reproduction. 2008; 23(6): 1439-46.

28.Baillargeon J, Iuorno M, Apridonidze T, Nestler JE .Uncoupling between insulin and release of a D-chiroinositol-containing inositolphosphoglycan mediator of insulin action in obese women with polycystic ovary syndrome. Metabolic Syndrome and Related Disorders. 2010; 8(2):127-35.

29.Pasquali R, Gambineri A. Insulin-sensitizing agents in polycystic ovary syndrome. European Journal of Endocrinology. 2006;154(6):763-75.

30.Kolodziejczyk B, Duleba A, Spaczynski R, Pawelczyk L. Metformin therapy decreases hyperandrogenism and hyperinsulinemia in women with polycystic ovary syndrome. Fertil Steril. 2000; 73(6):1149-54.

31.Trolle B, Flyvbjerg A, Kesmodel U, Lauszus FF. Efficacy of metformin in obese and non-obese women with polycystic ovary syndrome: a randomized, doubleblinded, placebo-controlled crossover trial. Hum Reprod. 2007;22(11):2967-73.
32.Palomba S, Falbo A, Di Cello A, Cappiello F, Tolino A, ZulloF. Does metformin affect the ovarian response to gonadotropins for in vitro fertilization treatment in patients with polycystic ovary syndrome and reduced ovarian reserve? A randomized controlled trial. FertilSteril. 2011; 96(5):1128-33.

33.Baillargeon J, Iuorno M, Jakubowicz D, Apridonidze T, He N, Nestler JE. Metformin therapy increases insulinstimulated release of D-chiro-inositol-containing inositolphosphoglycan mediator in women with polycystic ovary syndrome. J Clin Endocrinol Metab. 2004; 89(1):2429.

34.Unfer V, Nestler J, Kamenov Z, Prapas N, Facchinetti F. Effects of Inositol(s) in Women with PCOS:A systematic review of randomized controlled trials. International Journal of Endocrinology.2016.2016. 1-12.

35.Unfer V, Carlomagno G, Papaleo E, Vailati S,Candiani M, Baillargeon JP. Hyperinsulinemia alters myoinositol to dchiroinositol ratio in the follicular fluid of patients with PCOS. Reproductive sciences. 2014; 21(7): 854-58

36.Bizzarri M1, Carlomagno G. Inositol: History of an effective therapy for Polycystic Ovary Syndrome. Eur Rev Med Pharmacol Sci.2014 Jul;18(13):1896-903

37. Clements RS Jr, Darnell B. Myo-inositol content of common foods: development of a high-myo-inositol diet. Am J Clin Nutr 1980;33(9):1954-67.

38.Isabella R, Raffone E. Does ovary need D-chiro-inositol? Journal of Ovarian Research 2012;5:14:1-5

39. Unfer V, Porcaro G. Updates on the myo-inositol plus Dchiro-inositol combined therapy inpolycystic ovary syndrome. Expert Rev. Clin. Pharmacol; 2014;7(5):623-31.

40. Morinaga T, Ashida H, Yoshida K. Identification of two scylloinositol dehydrogenases in Bacillus Subtilis. Microbiology. 2010 May;156(5):1538-46.

41.Biradar V, Tengli S. Myoinositol in PCOS. Journal of Evidence based Medicine and Healthcare. 2014 December 15;1(15): 1927-36.

42.Pizzo A, Lagana A, Barbaro L. Comparison between effects of myo-inositol and D-chiro-inositol on ovarian function and metabolic factors in women with PCOS. Gynecol Endocrinol. 2014;30(3):205-8

43.Carlomagno G, Unfer V, Roseff S. The D-chiro-inositol paradox in the ovary. Fertil Steril. 2011 Jun 30; 95(8):2515-6

44.Laganà A, Rossetti $\mathrm{P}$, Buscema, Vignera S,Condorelli R, Gullo G. Metabolism and Ovarian Function in PCOS Women : A Therapeutic Approach with Inositols. International Journal of Endocrinology. 2016, Article ID 6306410, 9 pages 
45.Nordio M, Proietti E. The Combined therapy with myoinositol and D-Chiro-inositol reduces the risk of metabolic disease in PCOS overweight patients compared to myoinositol supplementation alone. European Review for Medical and Pharmacological Sciences. 2012;16: 575-81.

46.Colazingari S, Treglia M, Najjar R, Bevilacqua A.The combined therapy myo-inositol plus D-chiro-inositol, rather than D-chiro-inositol, is able to improve IVF outcomes: results from a randomized controlled trial. Arch Gynecol Obstet. 2013 Dec; 288(6):1405-11

47.Abdelhamid A, Madkour W, Borg T, Tamer F. Inositol versus metformin administration in polycystic ovarian disease patients: a case-control study. Evid Based Women Health. 2015;5(3):93-8

48.Facchinetti F, Bizzarri M, Benvenga S, D'Anna R, Lanzone A, Soulage C. Results from the International Consensus Conference on Myo-inositol and D-chiroinositol in Obstetrics and Gynecology: the link between metabolic syndrome and PCOS. European Journal of Obstetrics \& Gynecology and Reproductive Biology. 2015 Dec;195:72-6.

49.Bevilacqua A, Carlomagno G, Gerli S, Montanino Oliva M, Devroey P, Lanzone A. Results from the International Consensus Conference on myo-inositol and D-chiro-inositol in Obstetrics and Gynecology - assisted reproduction technology. Gynecol Endocrinol, Early Online. 2015;31(6):441-6.

50.Benelli E, Ghianda S, Cosmo C, Tonacchera MA. Combined Therapy with Myo-Inositol and D-Chiro-Inositol Improves Endocrine Parameters and Insulin Resistance in
PCOS Young Overweight Women. International Journal of Endocrinology. 2016; Article ID 3204083, 5 pages.

51.Minozzi M, Nordio M, Pajalic R. The Combined therapy myo-inositol plus D-Chiro-inositol, in a physiological ratio, reduces the cardiovascular risk by improving the lipid profile in PCOS patients. Eur Rev Med Pharmacol Sci. 2013; 17(4):537-40

52.Pande M, Seal A, Mishra S, Dasgupta A, Sengupta M, Dastider R. The effects of combined therapy of myo-inositol and D-chiro inositol in reduction of the individual components of metabolic syndrome in overweight PCOS patients compared to myo-inositol supplementation alone: a prospective randomised controlled trial. Int J Reprod Contracept Obstet Gynecol. 2017 Jul; 6(7):2939-43

53.Carlomagno G, Unfer V. Inositol safety: clinical evidences. European Review for Medical and Pharmacological Sciences. 2011;15:931-36.

54.Pintaudi B, Di Vieste G, Bonomo M. The Effectiveness of Myo-Inositol and D-Chiro Inositol Treatment in Type 2 Diabetes. International Journal of Endocrinology. 2016;2016:9132052.

\footnotetext{
Abhijeet G Malvi ${ }^{1}$, Alok Chaturvedi ${ }^{2}$, Sonal V Mehta ${ }^{3}$, Kishore R Sonkusare ${ }^{4}$, Nilanj S Dave ${ }^{5}$

${ }^{1}$ Senior Manager, Medical Affairs; ${ }^{2}$ Senior VP, Medical Affairs; ${ }^{3}$ Deputy General Manager, Medical Affairs;

${ }^{4}$ Assistant General Manager, Medical Affairs;

${ }^{5}$ Assistant General Manager, Medical Affairs. Intas Pharmaceuticals Ltd, Ahmedabad, Gujrat, India.
} 